and pictures, particularly pieces which illustrate the history of steam navigation and of steam locomotion generally.

$\mathrm{Mr}$. Bradlee has not been content merely to collect but has also written many valuable treatises pertaining to the subjects of his. interest. Some of them are Piracy in the West Indies and Its Suppression (I921), Colonial Trade and Commerce, 1733-1774, History of the Boston and Maine Railroad, etc. Many of the books are profusely illustrated from their author's own collections.

Mr. Bradlee's work shows very well how remarkably useful antiquarian collections can be. History must be written not merely from documents, but also from every type of physical survival. In the industrial sphere, documents and collections are particularly useful when they go hand in hand.

\title{
The First Moving Picture on Record
}

THE moving pictures, however much critics and doctors of divinity. may lament their prevalence, as corrupters of the public taste or morals, are come upon us as an established fact. The Harvard Business School recognized the state of affairs by arranging a course of lectures for the students, given by some of the most prominent men in the industry; and our Secretary has recently come upon some timely information about its origin, through $\mathrm{Mr}$. A. C. Rulofson, of San Francisco, one of our members. It is, indeed, no other than the story of the first moving picture, made in I 872 at Palo Alto, on the stock farm of the Honorable Leland Stanford; and it was made for the purpose of settling a dispute over whether or not the feet of a trotting horse are at any time all off the ground at once. The photographer was Eadweard Muybridge, a temperamental genius, who copyrighted his photographs, unknown to Stanford, and when the latter gave the results of the experiment (which, by the way, decided the controversy in the affirmative) to his friend J. D. B. Stillman to write up, Muybridge brought suit for infringement of copyright. Stanford, exasperated, refused to contest the suit, and withdrew his book from circulation, with the consequence that there are very few copies extant.

Muybridge published other books later, however, describing his. further experiments, with more elaborate equipment, under the auspices of the University of Pennsylvania. His earlier apparatus consisted of a battery of twelve cameras, in which the exposures. 
were made successively by the completion of a magnetic circuit as the horse passed in front of each camera, and broke a string which was stretched across his path and connected with the camera. Later, Muybridge developed a method of exhibiting his photographs as a continuous moving picture, by means of a contrivance described by one of the London papers as "a magic lantern run mad," with which he astonished audiences in this country and in Europe. It is interesting to note, however, that while Muybridge was introducing one new art, he was still as skeptical as the next man of the possibilities of another. In speaking of his work with flying insects, he expresses the expectation that the "ingenious gentlemen who are persistently endeavoring to overcome the obstacles in the construction of an apparatus for aerial navigation, will perhaps some day be awakened by the fact that the only successful method of propulsion will be found in the action of the wing of an insect."

\section{Council of Foreign Bondholders}

Throvgr the generosity of Mr. W. L. Raymond of Wayland, Massachusetts, the Library now has a complete set of the annual reports of the Council of the Corporation of Foreign Bondholders, of London. The series begins with 1873 and comes down to date. Mr. Raymond presented the volumes to 1904, and the rest have come direct from the Council itself, which also very courteously supplied an earlier report which happened to be missing. Of late years, the reports have been running to several hundred pages each. Much valued by the economist and financier, these reports are mines of information on the loans of foreign states and the financial conditions obtaining therein.

\section{Notice of Annual Meeting}

THE annual meeting of The Business Historical Society which has been delayed beyond the regular date in January, is now scheduled for June 3, which is the day preceding the Dedication Day for the new buildings of the Harvard Business School. It is hoped that all of our members who can will be in Cambridge at that time for both of these events. 